\title{
PROBLEMS ON TERMINOLOGY AND THEORETICAL DESCRIPTION OF LANGUAGE DERIVATION LEVELS
}

\author{
Tatiana M. Shkapenko \\ Immanuel Kant Baltic Federal University, Kaliningrad, Russia \\ Svetlana S. Vaulina \\ Immanuel Kant Baltic Federal University, Kaliningrad, Russia
}

\begin{abstract}
The paper focuses on the system of terms used in Russian linguistics to denote the processes of language derivation. The existence of significant contradictions in their using is explained by the improper assignment of the generic term "derivation" to a separate language level - word formation. It is argued that a single-word nonattributive term should serve the purpose of nominating a concept that applies to all levels of the language. The terms denoting different varieties of derivation should include attributive characteristics, as it is in the case of terminology combination "semantic derivation". The features of the cognitive mechanisms underlying each of the types of derivation are determined, and the degree of their relevance to the development criterion as a core meaning of the lexeme "derivation" is established. A general typology of derivational processes is proposed. The term "derivation" within this typology is used for denoting the process of secondary nominative signs formation in hyperonimic sense, which includes the semantic, morphological and graphical derivation levels. The internal classification of each of the above-mentioned levels is developed. The main differences between them are presented with the help of formalized semantic records. The belonging of semantic and morphological derivation to the system language processes is proved, while graphoderivation is described as an aside-system phenomenon based on the game deconstruction of a language sign and violation of the conventions of its homogeneous semiotic representation.

Key words: derivation, semantic derivation, word formation, semantic word formation, graphoderivation.

Citation. Shkapenko T.M., Vaulina S.S. Problems on Terminology and Theoretical Description of Language Derivation Levels. Vestnik Volgogradskogo gosudarstvennogo universiteta. Seriya 2. Yazykoznanie [Science Journal of Volgograd State University. Linguistics], 2020, vol. 19, no. 6, pp. 204-215. (in Russian). DOI: https:// doi.org/10.15688/jvolsu2.2020.6.16
\end{abstract}

\section{ПРОБЛЕМЫ ТЕРМИНОЛОГИЗАЦИИ И ТЕОРЕТИЧЕСКОГО ОПИСАНИЯ УРОВНЕЙ ЯЗЫКОВОЙ ДЕРИВАЦИИ}

Татьяна Михайловна Шкапенко

Балтийский федеральный университет им. Иммануила Канта, г. Калининград, Россия

\section{Светлана Сергеевна Ваулина}

Балтийский федеральный университет им. Иммануила Канта, г. Калининград, Россия

\footnotetext{
Аннотация. В статье анализируется сложившаяся в отечественной лингвистике система терминов, используемых для обозначения процессов языковой деривации. Наличие значительных противоречий в способах терминологизации объясняется неправомерным присвоением родового термина «деривация» отдельному языковому уровню - словообразованию. Обосновывается, что однословный безатрибутивный
} 
термин должен служить целям номинации понятия, относящегося ко всем уровням языка. Терминологизация разновидностей деривации должна включать признаковые характеристики, как это имеет место в случае сочетания «семантическая деривация». Определены особенности когнитивных механизмов, лежащих в основе каждого из типов деривации, установлена степень их релевантности критерию развития как понятию, составляющему ядро значения лексемы «деривация». Предложена общая типология деривационных процессов, в рамках которой термин «деривация» имеет общее значение процесса образования вторичных номинативных знаков, включающего семантический, морфологический и графический уровни. Разработана внутренняя классификация каждого из уровней, различия между которыми представлены с помощью формализованных семантических записей. Доказана принадлежность семантической и морфологической деривации к системным языковым процессам. Графодеривация описана как внесистемное явление, основанное на игровой деконструкции языкового знака и нарушении конвенций его гомогенной семиотической репрезентации.

Ключевые слова: деривация, семантическая деривация, словообразование, семантическое словообразование, графодеривация.

Цитирование. Шкапенко Т.М., Ваулина С.С. Проблемы терминологизации и теоретического описания уровней языковой деривации // Вестник Волгоградского государственного университета. Серия 2, Языкознание. -2020. - Т. 19, № 6. - С. 204-215. - DOI: https://doi.org/10.15688/jvolsu2.2020.6.16

\section{Введение}

«На рубеже XX-XXI вв. русский язык, отвечая на знаковые цивилизационные вызовы современной эпохи, демонстрирует значительный потенциал динамического развития, что проявляется прежде всего в деривационных процессах» [Николина, Рацибурская, Фатхутдинова, 2020, с. 5]. Активизация данных процессов осуществляется на различных языковых уровнях, в первую очередь на морфологическом (возникновение значительного количества новых словообразовательных единиц) и на семантическом (образование новых значений лексических единиц). Теоретическое описание двух вышеуказанных уровней деривации осложняется противоречиями, существующими в области их терминологизации. Цель данной статьи - внести необходимые коррективы в категориально-понятийный аппарат формирующейся науки «дериватология» и разработать типологию деривационных уровней с учетом специфики когнитивных механизмов, лежащих в основе трансформации языковых знаков, и характера образуемых дериватов.

\section{Материал и методы исследования}

Теоретико-методологической базой исследования послужили фундаментальные труды в области лингвосемиотики и семантики [Апресян, 1974; Карцевский, 1965; Колесов, 2002; и др.], дериватологии, семантической деривации и словообразования [Голев, 1998; Зализняк, 2001; Кубрякова, 1990; Марков 1981; и др.]. При анализе противоречий в области категориально-понятийного аппарата дериватологии в качестве логико-философской основы использовались восходящие к Аристотелю положения о классическом способе определения понятий через род и видовое отличие (definitio per genus proximum et differentiam specificam). В процессе типологического описания различных уровней деривации применялись семантико-когнитивный анализ и принципы формализации его результатов в виде семантических записей.

Материалом исследования послужили научные монографии и статьи российских авторов, посвященные изучению проблем языковой деривации.

\section{Результаты и обсуждение}

\section{Деривация / семантическая деривация / деривация (словообразование)}

Вопрос о формах и способах преобразования языковых знаков необходимо предварить анализом понятия деривация в том его виде, который оно получило в лингвистических науках. Начнем с того, что в употреблении данного термина в лингвистике имеет место отчетливо выраженная асимметрия, обнаруживающаяся во взаимоотношении понятий деривация / семантическая деривация / деривация (словообразование). 
С одной стороны, термин деривация в трудах по языкознанию используется в качестве гиперонима, обозначающего процесс развития или преобразования языковых единиц любого уровня. В наиболее обобщенном виде дефиниция рассматриваемого термина была предложена Н.Д. Голевым, характеризующим деривацию как «важнейшую форму оязыковления детерминационного содержания, фундаментальный и универсальный способ представления нового на базе исходных суппозиций» [Голев, 1998, с. 65]. Инвариантная формула деривационных процессов описывается ученым как «данное плюс новое», а структура моделей, в которых они опредмечиваются, формализуется следующим образом: $« H=S+h »$, где $H$ - содержание высшего; $S$ - содержание, заимствованное высшим из низшего; $h$ - прирост сложности, специфическое содержание, модификационный ингредиент [Голев, 1998, с. 65].

Изложение онтологических и гносеологических основ языковой деривации находим в известной работе С.О. Карцевского об асимметричном дуализме языкового знака. Языковой знак характеризуется в ней как семиологическая данность, детерминирующая направление собственной эволюции. «Если бы знаки были неподвижны и каждый из них выполнял только одну функцию, язык стал бы простым собранием этикеток. Но также невозможно представить себе язык, знаки которого были бы подвижны до такой степени, что они ничего бы не значили за пределами конкретных ситуаций. Из этого следует, что природа лингвистического знака должна быть неизменной и подвижной одновременно. Призванный приспособиться к конкретной ситуации, знак может измениться только частично; и нужно, чтобы благодаря неподвижности другой своей части знак оставался тождественным самому себе» [Карцевский, 1965, c. 85].

Следует заметить, что предложенное С.О. Карцевским описание механизмов эволюции знака относится к изменениям плана содержания языкового знака при сохранении неизменным плана его выражения. С.О. Карцевский пишет: «В каждый данный момент мы имеем только два звена, относящихся друг к другу как знак транспонированный, знак в переносном смысле, к знаку “адекватному" и сохраняющихся в контакте в силу принципа tertium comparationis» [Карцевский 1965 , с. 85]. Указание на использование знака в переносном смысле, а также включение в описание принципа tertium comparationis ограничивают релевантность предложенного ученым истолкования только до процессов приобретения знаком переносного значения, то есть до семантической деривации.

Несмотря на то что изучение семантических преобразований слова имеет многолетнюю традицию, термин семантическая дериваџия был введен в лингвистический обиход со значительным опозданием. Его спорадическое использование отмечается в работах с 80-х гг. ХX столетия [Шмелев, 1973, с. 191; Апресян, 1974, с. 175, 187], где он употребляется в основном для характеристики отношений производности между значениями слова, именуемыми Д.Н. Шмелевым «эпидигматическими». Регулярное использование сочетания семантическая деривачия в работах отечественных лингвистов начинается с 90-х гг. [Кустова, Падучева, 1994; Кустова, 1998; Никитин 1996; и др.]. М.В. Никитин определяет содержание данного понятия как образование производных значений от исходных без изменения формы знаков, которое совершается по моделям семантической деривации метафорической, метонимической, гипонимической [Никитин, 1996, с. 375$].$

Анна А. Зализняк объясняет все большее распространение термина свойственным его семантике комбинированием процессуальности и результативности: «Данный термин является, по-видимому, наиболее удачным - в частности потому, что ценой довольно незначительного насилия он может быть применен не только к процессу, но и к результату, т. е. к конкретным фактам семантических переходов, каждый из которых может быть назван “семантической деривацией”. Этот термин удобен еще и потому, что он указывает на производность, не уточняя ее природы, тем самым он в равной мере применим как к синхронии, так и к диахронии» [Зализняк, 2001, с. 13].

Релевантность термина для именования какого-либо процесса или явления определяется его соотнесением с первичным значе- 
нием в языке-доноре. Этимологический анализ слова деривация свидетельствует о частичной его предрасположенности к обозначению процессов развития, изменения, преобразования или эволюции. Изначально слово деривация (от лат. derivatio) имело значение «отведение, отклонение» (ССИС, c. 190), что послужило основой для возникновения узкоспециализированных значений в точных науках: «отвод воды из реки, водохранилища или другого водоема для целей судоходства, орошения, транспортировки воды к гидроэлектростанции или насосной станции» в гидротехнике (ССИС, с. 190), «метод движения одной функции от другой на основе постоянных коэффициентов» в математике (ССИС, с. 190), «боковое отклонение вращающегося при полете снаряда, пули от плоскости бросания (ЭС, с. 323). Как видим, во всех терминоупотреблениях реализуется общая сема «движение в сторону», и только в лингвистическом дискурсе профессиональный ученый-номинатор деактуализирует ее, осуществляя операцию по расширению значения, то есть подвергая само слово деривация семантической деривации.

Несмотря на отмеченную Анной А. Зализняк удачность терминосочетания семантическая деривачия, оно долгое время оставалось и продолжает оставаться в тени термина деривация, используемого для обозначения процессов словообразования. Е.С. Кубрякова отмечает, что «образование новых слов (с помощью формальных средств) нередко именуется также деривацией, производные же и сложные слова как результаты процесса деривации обозначаются тогда общим термином “дериваты”. В зарубежной лингвистике существует тенденция приравнивать словообразование к деривационной морфологии как учению о формальных свойствах дериватов и реализующих их морфологических структурах» [Кубрякова, 1990, с. 468]. По мнению Е.С. Кубряковой, данное «уравнивание» типично только для зарубежной лингвистики. Однако следует признать, что оно не в меньшей степени характерно и для русского языковедческого дискурса. Практически все толковые словари русского языка приводят в качестве одного из значений слова деривачия «словообразование», причем многие лексикографы именно его ставят на первое место. Например:

Деривация, ж. Образование новых слов аффиксальным или безаффиксным способом; словопроизводство (в лингвистике) (НСРЯ, с. 276).

В качестве синонимичных термины словообразование и деривачия используются и в многочисленных работах отечественных лингвистов. Данная «узурпация» словообразованием общего термина деривация сама по себе содержит категориальную ошибку. Если термин претендует на роль родового понятия (genus proximum), относящегося к процессу преобразования языковых единиц всех уровней, то в наименованиях его подвидов должна присутствовать атрибутивная характеристика, определяющая специфику каждого из них (differentia specifica). Данное видовое различение имеет место в терминосочетании семантическая деривация, однако отсутствует в терминологическом обозначении морфологических способов деривации.

Вышеуказанная логическая ошибка, или номинативный промах, отчасти может быть объяснена хронологией опережающего присвоения словообразованию родового термина деривация. Уже в 1936 г., выступая на Копенгагенском лингвистическом конгрессе, Е. Курилович не только вводит понятия лексической и синтаксической деривации, но и отмечает равенство терминов дериваиия и лексическая дериваџия: «Теперь нетрудно понять, чем отличается синтаксическая деривация от того, что называют лексической деривацией, или короче - деривацией» [Курилович, 1962, с. 62].

До возникновения потребности в обозначении с помощью данного термина процесса семантического развития языкового знака, а также появления осознания процесса деривации как многоуровневого языкового явления, «приватизация» словообразованием общего родового термина не вызывала особых проблем и противоречий. В новых условиях все настойчивее обнаруживают себя вопросы о правомочности употребления родового наименования дериващия по отношению только к одной ее языковой разновидности, о необходимости терминологической коррекции или по крайней мере осознания логической дисфунк- 
циональности, которая возникает при отнесении общей, родовой терминолексемы только к одному уровню развития языка. Отметим, что даже в тех работах, авторы которых эксплицитным образом указывают на наличие гиперонимического понимания деривации, ощущается сила инерции, в соответствии с которой «законное право» на использование термина принадлежит именно словообразованию. Так, представитель Казанской лингвистической школы (далее - КЛШ) Г.А. Николаев указывает, что деривационная система языка представляет собой межуровневое явление, что «деривационный аспект может быть применен к явлениям любого языкового яруca, однако основной сферой его применения является сфера двусторонних языковых единиц: слов, словоформ, словосоединений (словосочетаний, предложений). Таким образом, устанавливается деривационная система лексики (словообразование), морфологии (формообразование), синтаксиса (образование вторичных синтаксических единиц)» [Николаев, 2007, c. 11].

Как следует из высказывания, область семантической деривации к числу основных сфер динамических изменений отнесена не была ${ }^{1}$. Из этого и других многочисленных примеров можно сделать вывод, что давно свершившийся акт канонизации словообразования в качестве эквивалента деривации препятствует пониманию термина в более широком значении, рождая тем самым проблемы в выстраивании отношений внутри категориальнопонятийного аппарата общей дериватологии как важнейшей области диахронно-синхронного языкознания.

\section{Словообразование \\ и семантическая деривация: степень релевантности терминов}

Как было показано выше, в процессе семантической деривации анализируемый нами лингвистический термин лишился семы «движение в сторону», или «отклонение», и стал использоваться для обозначения общего процесса развития языковых элементов. Толковые словари фиксируют у слова развитие следующее значение: «процесс закономерного изменения, перехода из одного состояния в другое, новое; постепенный переход от старого состояния к новому, от простого к сложному, от низшего к высшему» (ТСРЯ, с. 791). В философском словаре развитие определяется как «поступательное движение, эволюция, переход от одного состояния к др. Р. противопоставляется “творению”, “взрыву”, появлению из ничего» (ФС, с. 836 ). В.В. Колесов характеризует развитие как «развертывание в определенном направлении заданных системой импульсов, экспликацию качеств, которые определены началом и обеспечивают поступательный ход изменений» [Колесов, 2002, c. 97].

Прилагая данные толкования «развития» к двум зафиксированным практикой лингвистического дискурса референтным областям - словообразованию (деривации) и семантической деривации, обнаруживаем, что именно последнее в наибольшей степени вписывается в алгоритм поступательного движения. Независимо от способа формирования полисемии, смысл нового лексико-семантического варианта проистекает из исходного, или уже развившегося на его основе значения. В то же время процесс словообразования, носящий имя деривации, в сущности, лишен элементов поступательного, эволюционного развития.

Как известно, под словообразованием понимается «образование новых слов путем соединения друг с другом корневых и аффиксальных морфем, а также основ (баз) данного языка в разных комбинациях по определенным моделям, включающим правила чередования звуков, определяющим тот или иной характер соединения и т.п.» (СЛТ, c. 424). Е.С. Кубрякова характеризует словообразование как «образование слов, называемых производными и сложными, обычно на базе однокорневых слов по существующим в языке образцам и моделям с помощью аффиксации, словосложения, конверсии и других формальных средств» [Кубрякова, 1990, c. 467]. При любом истолковании речь идет об образовании производных слов, но не о процессе поступательного развития языковых знаков. С когнитивной точки зрения акт словообразования интенционален и одномоментен и представляет собой чаще всего операцию по комбинаторике смыслов, содержащихся в морфологических компонентах. В процес- 
се словостроительства отсутствует базовое для деривационных процессов свойство континуальности. Здесь нет единого объекта развития, в котором на старое содержание накладывается новое, здесь имеет место процесс парадигматического сложения морфосемантических компонентов с целью создания новой языковой единицы.

Объекты словопроизводства раздельны формально и семантически, ни один из них не претерпевает качественного изменения, лишь в совокупности своей они порождают новый знак, производный от их общей семантики по определенным, присущим конкретному языку моделям. Порождаемые при этом дериваты вряд ли можно описать как результат эволюции входящих в их состав компонентов. Элемент насильственности описания комбинаторной техники словообразования в терминах деривации можно обнаружить и в грамматических формах, используемых при характеристике процесса: ученые-дериватологи пишут не о дериваиии морфем, а дериваиии от морфемы. Как указывает И.М. Некипелова, «ученые... выделяют следующие типы деривации: первичная деривация - деривация от корня, вторичная деривация деривация от производной основы, прогрессивная деривация - аффиксация, регрессивная деривация - дезаффиксация» [Некипелова, 2011, с. 35].

Основанием для отнесения области словообразования к деривации является не механизм поступательного развития знака, а «образование новых слов (дериватов) от уже имеющихся в языке (Крысин, с. 218). В то же время семантическая деривация опирается на механизм эволюционирования, при котором языковой знак проходит путь от окказиональных «инновационных» употреблений до постепенной узуализации новых смыслов и их фиксации словарями в качестве новых лексико-семантических вариантов (далее - ЛСВ). Заметим, что именно эволюционный характер неосемантизации знака становится онтологическим основанием для появления концепции КЛШ [Марков, 1981; 2001; Николаев, 2007; и др.], постулирующей необходимость разграничения семантической деривации как процесса и семантического словообразования как стадии его завершения и перехода на системный языковой уровень.

\section{Семантическая деривация \\ и семантическое словообразование}

Проблемы интерпретационного характера возникают и в случае с терминосочетанием семантическое словообразование. Если следовать логике научной терминологизации, то атрибутивный признак должен именовать некую разновидность словообразования и дифференцировать семантическое словообразование от иных, несемантических его ипостасей. Поскольку процесс рождения слова без возникновения смысла невозможен по определению (если не принимать во внимание экспериментальных лингвопоэтических практик), то данная терминологизация порождает эффект тавтологической номинации.

Легитимизацию термина оправдывает его авторское использование представителями КЛШ во главе с профессором В.М. Марковым, доказывающими необходимость разграничения процессов деривации как актов речепроизводства от его результатов как фактов перехода результатов семантического развития на уровень языковой системы [Марков, 1981; 2001]. В сущности, речь идет о том, можно ли интерпретировать уже зафиксированные словарями акты полисемии как элементы эпидигматики единой лексической единицы или же необходимо каждый раз констатировать акт возникновения нового слова.

Г.А. Николаев настаивает на единственно верной интерпретации конечных результатов семантической деривации как «семантического словопроизводства». По его мнению, «признание семантического словообразования (по формуле: сколько значений - столько слов) упраздняет феномен полисемии в принятом смысле. И с этим никак не могут согласиться традиционно мыслящие языковеды. Полисемия является в науке само собой разумеющейся истиной, не требующей доказательств. К сожалению, языкознание сильно страдает от обилия таких истин» [Николаев, 2007, с. 15]. Признание собственной беспомощности в преодолении силы научной инерции вместе с убежденностью в правоте концепции КЛШ выражается в проведении автором параллели между наивными формами категоризации мира и нежеланием признать факт образования слова каждый раз, как имеет место завершение 
акта деривации. «Ссылка на само собой разумеющуюся истину при разговоре о полисемии и семантическом словообразовании напоминает профанное отнесение арбуза, огурца, дыни и т. п. к овощам, в то время как с научной точки зрения это ягоды (по типу плода)» [Николаев 2007, с. 15].

Признавая обоснованность утверждений о необязательной узуализации результатов семантических изменений языкового знака, отметим все же, что введение наряду с термином семантическая деривация дополнительного термина семантическое словообразование способно еще более осложнить проблемы терминологической дифференциации. Даже если мы отвлечемся от основной категоризационной ошибки - присвоения родового термина отдельному виду деривации, то и в этом случае возникает вопрос, насколько правомочна интерпретация нового ЛСВ как нового слова при каждой смене денотата. По мнению Г.А. Николаева, «смена денотата свидетельствует, что произошла деривация. Образованное таким путем слово становится в иной лексико-семантический ряд (ср.: нос, ухо, рот, губа и т. д. и нос, корма, бак, камбуз, каюта)» [Николаев, 2007, c. 15]. На наш взгляд, сохранение неизменным плана выражения, а также выводимость смысла семантического производного дают все основания для его характеристики в рамках полисемии или эпидигматики, а в случае распадения генетических связей - для его квалификации как омонима, что и применяется в лексикографической практике.

\section{Графодеривация как новый тип деривации \\ языкового знака}

Изменения в современной языковой ситуации, развитие частной ономасиологической инициативы в рамках так называемого «коммерческого нейминга» привели к играм номинаторов с графическим обликом слова. В рамках теоретического описания плодов лингвокреативного бума появилось еще одно обозначение типа деривации - графодеривация. T.В. Попова описывает сущность данного явления как «способ образования новых слов с использованием приемов графической языковой игры» [Попова, 2007, с. 230]. Согласно
Н.В. Перцову, графодеривация представляет собой широко распространенный в настоящее время «окказиональный способ словообразования, в основе которого лежит принцип нарушения и обыгрывания графо-орфографической формы слова» [Перцов, 2001, с. 216].

Наиболее полная классификация нового вида деривации была предложена Т.В. Поповой, избирающей в качестве критериев типологизации элементы, используемые с целью образования графодериватов. В соответствии с этим выделяются: монографиксация (создание новообразований графическими средствами одного языка), полиграфиксация (создание лексем при использовании графических средств разных языков), кодографиксация (создание новообразований при помощи сегментных средств разных кодовых систем, одна из которых не является естественно-лингвистической), типографиксация (создание новообразований посредством супрасегментных средств графического оформления текста) [Попова, 2013].

Несмотря на разнообразие представленных выше операций по преобразованию графической формы знака, в их основе лежит единый когнитивный механизм. Лингвокреативный номинатор выделяет в составе графического изображения слова компонент, который может быть репрезентирован средствами другого языкового или внеязыкового кода. Результатами реграфизации становится эффект эквивокации, реализуемый, однако, на материале не целостного слова, а специально выделенной в нем части. Данный механизм может быть описан как дистинктивно-компаративный, поскольку операция выделения сегмента, содержащего в себе потенциал графической деривации, связана с его одновременным сопоставлением с альтернативными семиотическими средствами репрезентации.

Примечательно, что и в случае графодериватов продолжает довлеть сила терминологической инерции, в соответствии с которой графодеривация рассматривается как синоним словообразования. В отдельных работах встречаем термин графическое словообразование, а один из исследователей так называемых графических дериватов предпринимает попытку анализа соотношения графодериватов и слов, словосочетаний, фразеоло- 
гизмов или высказываний [Пучина, 2013]. Нетождественность графодеривата слову объясняется А.С. Пучиной на примере рекламного наименования магазина «НаСТОЯЩИЕ джинсы». По мнению исследователя, вмещая в себя значение «имеющий ценность, заслуживающий внимания», графодериват является более емкой в структурном и в смысловом планах, нежели слово, единицей. Последовательное сравнение с указанными выше единицами приводит автора к релятивному выводу о том, что «графодериваты трудно отнести к какому-либо уровню речи, однако наиболее близки они словообразовательному уровню» [Пучина, 2013, с. 103].

Утверждения о смысловом «превосходстве» искусственного деривата над словом как единицей естественного языка, а также о близости графодеривации к словообразованию следует признать дискуссионными. Принимая во внимание холистичность слова как динамического единства двух его сторон, необходимо отметить, что процесс творческой графоинтерпретации представляет собой дефрагментацию слова в результате вычленения в нем отдельного элемента, подвергающегося графической ресемиотизации. В случае монографиксации речь идет о процессе, обратном словосложению, об играх с «неморфологическими» компонентами слова. Эффект их креативного прочтения не результирует появлением более смыслоемкого знака, а, напротив, обращает внимание адресата на случайную, «незаконную» смысловую связь вычлененных в графическом облике слова компонентов. В рамках графодеривации имеет место интенциональная дефрагментация языкового знака, онтологически противостоящая словообразовательной комбинаторике морфем, направленной на создание системной языковой единицы.

В случае полиграфиксации, использующей средства разных языков, или кодографиксации, использующей средства различных семиотических систем, следует говорить о разрушении неписаных, основанных на естественной онтологии языкового знака правил фиксации звуковой оболочки слова с помощью графем, входящих в состав национального алфавита. Растущая популярность полиграфиксатов в эргонимах российских городов свидетельствует о влиянии английского языка, в то время как кодографиксаты являют собой свидетельство гибридизации самого мышления современного человека, в котором иконическая составляющая занимает все большее место. В отличие от семантической и морфологической деривации, основывающихся на имманентных для языкового знака или отдельных морфем исходных суппозициях, в процессе графодеривации на первое место выходит индивидуальный языковой субъект, который реализуется в акте номинации как гибрид homo ludens и homo videns ${ }^{2}$, стремясь привлечь внимание креативного потребителя.

Таким образом, будучи игровой, гетерогенной репрезентацией выделенных индивидом компонентов знака, графическая деривация представляет собой скорее процесс деконструкции слова, а присущая ей цель - нарушить существующие конвенции знакостроительства - по определению ставит данный процесс вне языковой системы. Эффекты графодеривационного творчества не следует относить к уровню речевой деятельности: являясь элементами коммерческого нейминга, они представляют собой особый тип «одноразовых» номинативных единиц, привлекающих своей неконвенциональностью внимание целевой аудитории.

\section{Типология языковой деривации}

Деривация есть общий, универсальный процесс образования вторичных языковых знаков, отдельные уровни которого отличаются лежащими в их основе когнитивными механизмами, целями номинативных актов, типом мотивирующих элементов и образуемых дериватов. На основе данных параметров выделяются три уровня деривации: семантическая, морфологическая и графическая. Принимая во внимание поступательный характер смысловых трансформаций, в качестве эталонного типа деривации (в соответствии с теорией лучших, или прототипических, образцов Э. Рош [Rosch, 1973]) следует признать семантическую деривацию, в рамках которой происходит постепенное изменение содержания знака при сохранении плана его выражения. В этом случае в предложенной Н.Д. Голевым общей формуле деривации $(S+h=H)$ прирост содержания или 
модификационный ингредиент $h$ не имеет объективированного языкового выражения. Его место занимает когнитивная операция по переводу смысла из начальной в новую форму его бытования путем переноса значения, расширения или сужения, появления дополнительных коннотаций, реаксиологизации или деаксиологизации. Получаемые на выходе структуры имеют характер неосемантов или неосемантизмов, а процесс их образования может быть формализован с помощью следующей семантической записи:

$A / b+h=A / c$, где $A$ - план выражения; $b$ - план содержания; $h$ - когнитивная операция, вызывающая семантический сдвиг; $c$ план содержания образуемого семантического деривата.

Процесс семантической деривации детерминируется потребностью коллективного номинатора в адаптации содержания знака к изменяющимся познавательным или ценностным установкам общества.

Морфологическая деривация представляет собой процесс оперирования компонентами с целью создания новообразования из готового морфосемантического сырья. Получаемые на выходе структуры в соответствии с типом словообразовательного значения делятся на модификационные, мутационные и транспозиционные.

Формула модификационной деривации может быть описана как $\mathrm{A} / b+C / d=A C / b d$, где $A$ - план выражения корневой основы; $b$ - план ее содержания; $C$ - план выражения форманта; $d$ - план его содержания. Получаемый результат $A C / b d$ представляет собой линейную последовательность формальных значимостей $A C$, соответствующую сумме семантических значимостей $b d$. В случае мутационного типа словообразования формула деривации изменяется: $A / b+C / d=A C / f$, где $f$ обозначает возникновение нового, не выводимого из суммы смыслов словообразовательных компонентов плана содержания, или значения. Формула транспозиционной деривации может быть представлена следующим образом: $A / b+C / h=A C / b(h)$, где $A$-план выражения корневой основы; $b$ - план содержания; $C$ - план выражения форманта; $h$ - выполняемая им функция синтаксической перекатегоризации. Полученный результат
$A C / b(h)$ обозначает сохранение значения $b$ при его переводе в другую частеречную категорию с помощью элемента $h$.

В основе когнитивного механизма графодеривации лежит выделение определенного компонента языкового знака, имеющего потенциал двойной интерпретации. В рамках дистинктивно-компаративных операций в качестве tertium comparationis могут выступать элементы других алфавитов (латиница или старокириллическое написание) либо элементы других семиотических систем. Внесистемный характер графической деривации проявляется и на уровне его семантической записи, в которой слово $A$ в единстве его выражения и содержания подвергается произвольному разделению на компоненты $b$ и $c$, один из которых получает ресемиотизированное, особое представление в виде $h$, что может быть выражено формулой $A=b h(c)$.

\section{Выводы}

Развитие дериватологии как самостоятельной области языкознания требует внесения корректив в уже сложившийся категориально-понятийный аппарат. В соответствии с логикой терминообразования использование термина деривация представляется целесообразным только для обозначения родового понятия как межуровневого явления. Внутренняя классификация деривации строится на выделении разновидностей, терминологическое обозначение которых должно включать признаковые характеристики: морфологическая деривация (словообразование), семантическая деривация и графическая деривация. Особенности когнитивных процессов, составляющих базу для различных типов деривации, вместе с различиями в структуре соответствующих вторичных знаков свидетельствуют об онтологической и гносеологической неравноценности трех деривационных уровней. Семантическая и морфологическая деривация представляют собой системные языковые процессы, лежащие в основе перманентного поступательного развития языковой материи. Активизирующаяся в современных условиях графическая деривация должна быть охарактеризована как внесистемный феномен, основанный на механизме игровой деконструкции языкового знака. 


\section{ПРИМЕЧАНИЯ}

${ }^{1}$ Справедливости ради заметим, что данное игнорирование может быть объяснено характерной для КЛШ концепцией, согласно которой следует различать семантическую деривацию как процесс, не обязательно завершающийся образованием нового значения, и семантическое словообразование как уже свершившийся факт узуализации нового значения языкового знака.

2 Термин введен итальянским политологом Дж. Сартори для обозначения нового типа мышления с преобладанием визуальных форм восприятия и когнитивной обработки [Sartori, 2000].

\section{СПИСОК ЛИТЕРАТУРЫ}

Апресян Ю. Д., 1974. Лексическая семантика. М. : Наука. 251 с.

Голев Н. Д., 1998. Деривация и мотивация как формы оязыковленной детерминации: инварианты и варианты // Очерки по лингвистической детерминологии и дериватологии русского языка / под ред. Н. Д. Голева. Барнаул : Изд-во Алт. ун-та. С. 65-84.

Зализняк Анна А., 2001. Семантическая деривация в синхронии и диахронии: проект «Каталога семантических переходов» // Вопросы языкознания. № 2. С. 13-25.

Карцевский С. О., 1965. Об асимметрическом дуализме лингвистического знака // Звегинцев В. А. История языкознания XIX-XX веков в очерках и извлечениях. В 2 ч. Ч. 2. М. : Просвещение. С. 85-90.

Колесов В. В., 2002. Философия русского слова. СПб. : ЮHА. 444 c.

Кубрякова Е. С., 1990. Словообразование // Лингвистический энциклопедический словарь. М. : Сов. энцикл.. С. 467-469.

Курилович Е., 1962. Очерки по лингвистике : сб. ст. М. : Изд-во иностр. лит. $446 \mathrm{c.}$

Кустова Г. И., 1998. Производные значения с экспериенциальной составляющей // Семиотика и информатика. № 36. М. : Шк. «Яз. рус. культуры»; Рус. слов. С. 19-40.

Кустова Г. И., Падучева Е. В., 1994. Словарь как лексическая база данных // Вопросы языкознания. № 4. С. 96-106.

Марков В. М., 1981. О семантическом способе словообразования в русском языке. Ижевск : Изд-во Удмурт. ун-та. 29 с.

Марков В. М., 2001. Избранные работы по русскому языку. Казань : Изд-во ДАС. 274 с.

Некипелова И. М., 2011. К вопросу о разграничении понятий семантическая деривация и се- мантическое словообразование в диахроническом аспекте // Вестник Томского государственного университета. Филология. № 2 (14). C. 33-46.

Никитин М. В., 1996. Курс лингвистической семантики. СПб. : Науч. центр проблем диалога. $756 \mathrm{c.}$

Николаев Г. А., 2007. Теоретические проблемы русского словообразования. Казанская научная школа // Диалектное словообразование, морфемика и морфонология / под ред. Е. Н. Шабровой. СПб. : Наука ; Вологда : ВГПУ. С. 7-29.

Николина Н. А., Рацибурская Л. В., Фатхутдинова В. Г., 2020. Новые явления в сфере деривационных формантов как отражение динамики словообразовательной системы русского языка // Вестник Волгоградского государственного университета. Серия 2, Языкознание. Т. 19, № 2. С. 5-19. DOI: https:// doi.org/10.15688/jvolsu2.2020.2.1.

Перцов Н. В., 2001. Инварианты в русском словоизменении. М. : Яз. рус. культуры. 280 с.

Попова Т. В., 2007. Графодеривация в русском словообразовании конца XX - начала XXI в. // Русский язык: исторические судьбы и современность. III Международный конгресс исследователей русского языка : тр. и материалы. М. : МГУ. С. 230-231.

Попова Т. В., 2013. Креолизованные дериваты как элемент русской письменной коммуникации рубежа XX-XXI вв. // Лингвистика креатива-1 / под общ. ред. проф. Т. А. Гридиной. 2-е изд. Екатеринбург : Изд-во Урал. гос. пед. ун-та. C. 147-175.

Пучина А. С., 2013. Дериваты как особые единицы речи // Вестник Челябинского государственного университета. № 16 (307). Филология. Искусствоведение. С. 102-104.

Шмелев Д. Н., 1973. Проблемы семантического анализа лексики. М. : Наука. 280 с.

Rosch E., 1973. Natural categories // Cognitive Psychology. Vol. 7. P. 328-350.

Sartori C., 2000. Homo videns: Televisione e postpensiero. Rome: Laterza. $121 \mathrm{p}$.

\section{СЛОВАРИ}

Крысин - Крысин Л. П. Толковый словарь иноязычных слов. М. : Рус. яз., 2001. 856 с.

НСРЯ - Ефремова Т. Ф. Новый словарь русского языка. Толково-словообразовательный. В 2 т. T. 1. М. : Рус. яз., 2000. 1232 c.

СЛТ - Ахманова О. С. Словарь лингвистических терминов. М. : Сов. энцикл., 1969. 608 с. 
ССИС - Современный словарь иностранных слов / под ред. Н. М. Ланда. М. : Рус. яз., 1993. 740 с.

ТСРЯ - Толковый словарь русского языка с включением сведений о происхождении слов / под ред. Н. Ю. Шведовой. М. : Азбуковник, 2011. $1175 \mathrm{c}$.

$\Phi C-$ Философия : Энциклопедический словарь / под ред. А. А. Ивина. М. : Гардарики, 2004. $1072 \mathrm{c}$.

ЭС - Энциклопедический словарь. В 2 т. Т. 1 / гл. ред.: Б. А. Введенский (гл. ред.) [и др.]. М. : Сов. энцикл., 1963. 656 с.

\section{REFERENCES}

Apresyan Yu.D., 1974. Leksicheskaya semantika [Lexical Semantics]. Moscow, Nauka Publ. $251 \mathrm{p}$.

Golev N.D., 1998. Derivaciya i motivaciya kak formy oyazykovlennoy determinacii: invarianty $\mathrm{i}$ varianty [Derivation and motivation as forms of linguistic determination: invariants and variants]. Ocherki po lingvisticheskoy determinologii $i$ derivatologii russkogo yazyka [Essays on linguistic determinology and derivatology of the Russian language]. N.D. Golev (ed.). Barnaul, Izdatelstvo Altayskogo universiteta, pp. 65-84.

Zaliznyak Anna A., 2001. Semanticheskaya derivaciya v sinhronii i diakhronii: proekt "Kataloga semanticheskikh perehodov" [Semantic derivation in synchrony and diachrony: a project "The Catalog of semantic shifts"]. Voprosy yazykoznaniya, no. 2, pp. 13-25.

Karcevskiy S.O., 1965. Ob asimmetricheskom dualizme lingvisticheskogo znaka [On the asymmetric dualism of a linguistic sign]. Zvegincev B.A. Istoriya yazykoznaniya XIX-XX vekov $v$ ocherkakh $i$ izvlecheniyakh $v 2$ chastyakh [History of linguistics of the $19^{\text {th }}-20^{\text {th }}$ centuries in essays and extracts. In 2 parts]. Moscow, Prosveschenie Publ., part 2, pp. 85-90.

Kolesov V.V., 2002. Filosofiya russkogo slova [Philosophy of the Russian word]. Saint Petersburg, YuNA. 444 p.

Kubryakova E.S., 1990. Slovoobrazovanie [Word Formation]. Lingvisticheskiy enciklopedicheskiy slovar. Moscow, Sovetskaya enciklopediya, pp. 467-469.

Kurilovich E., 1962. Ocherki po lingvistike: sbornik statey [Essays on linguistics: a collection of articles]. Moscow, Izdatelstvo inostrannojy literatury. $446 \mathrm{p}$.

Kustova G.I., 1998. Proizvodnye znacheniya s eksperiencialnoy sostavlyayushchey [Derived meanings with an experiential component].
Semiotika i informatika. Moscow, Shkola "Yazyki russkoy kultury", "Russkie slovari", no. 36, pp. 19-40.

Kustova G.I., Paducheva E.V., 1994. Slovar kak leksicheskaya baza dannykh [Dictionary as a lexical database]. Voprosy yazykoznaniya, no. 4, pp. 96-106.

Markov V.M., 1981. O semanticheskom sposobe slovoobrazovaniya $v$ russkom yazyke [About the semantic method of word formation in the Russian language]. Izhevsk, Izdatelstvo Udmurtskogo universiteta. $29 \mathrm{p}$.

Markov V.M., 1981. Izbrannye raboty po russkomu yazyku [Selected works in the field of Russian language]. Kazan, DAS Publ. 274 p.

Nekipelova I.M., 2011. K voprosu o razgranichenii ponyatiy semanticheskaya derivaciya $\mathrm{i}$ semanticheskoe slovoobrazovanie v diahronicheskom aspekte [On demarcation and differentiation of terms "semantic derivation" and "semantic word formation" in the diachrony]. Vestnik Tomskogo gosudarstvennogo universiteta. Filologiya [Tomsk state university journal of philology], no. 2 (14), pp. 33-46.

Nikitin M.V., 1996. Kurs lingvisticheskoy semantiki [Course of linguistic semantics]. Saint Petersburg, Nauchnyy centr problem dialoga. $756 \mathrm{p}$.

Nikolaev G.A., 2007. Teoreticheskie problemy russkogo slovoobrazovaniya. Kazanskaya nauchnaya shkola [Theoretical problems of Russian word formation. Kazan scientific school]. Dialektnoe slovoobrazovanie, morfemika i morfonologiya: Monografiya [Dialect word formation, morphemics and morphonology]. E.N. Shabra (ed.). Saint Petersburg, Nauka Publ., Vologda, VGPU,pp. 7-29.

Nikolina N.A., Raciburskaya L.V., Fatkhutdinova V.G., 2020. Novye yavleniya $\mathrm{v}$ sfere derivacionnykh formantov kak otrazhenie dinamiki slovoobrazovatelnoy sistemy russkogo yazyka [New Phenomena in the Sphere of Derivation Formants as Reflection of the Dynamics of the Russian Language Word-Formation System]. Vestnik Volgogradskogo gosudarstvennogo universiteta. Seriya 2, Yazykoznanie [Science Journal of Volgograd State University. Linguistics], vol. 19, no. 2, pp. 5-19. DOI: https:// doi.org/10.15688/jvolsu2.2020.2.1.

Percov N.V., 2001. Invarianty v russkom slovoizmenenii [Invariants in Russian words inflection]. Moscow, Yazyki russkoy kultury Publ. 280 p.

Popova T.V. Grafoderivaciya v russkom slovoobrazovanii konca XX - nachala XXI v. [Graphoderivation in Russian word formation of 
the end of $20^{\text {th }}$ - beginning of $21^{\text {ed }}$ century]. Russkiy yazyk: istoricheskie sudby $i$ sovremennost. III Mezhdunarodnyy kongress issledovateley russkogo yazyka. Trudy $i$ materialy. Moscow, MGU, pp. 230-231.

Popova T.V., 2013. Kreolizovannye derivaty kak element russkoj pis‘mennoj kommunikacii rubezha XX-XXI vv. [Creolized derivatives as an element of Russian written communication at the turn of the $20^{\text {th }}-21^{\text {d }}$ century]. Lingvistika kreativa-1 [Linguistics of creativity]. T.A. Gridina (ed.), 2 ed. Ekaterinburg, Izdatelstvo Uralskogo gosudarstvennogo pedagogicheskogo universiteta. P. 147-175.

Puchina A.S., 2013. Derivaty kak osobye edinicy rechi [Graphical derivatives as unique units of speech]. Vestnik Chelyabinskogo gosudarstvennogo universiteta [Bulletin of Chelyabinsk state university], no. 16 (307). Filologiya. Iskusstvovedenie, pp. 102-104.

Shmelev D.N., 1973. Problemy semanticheskogo analiza leksiki [Problems of semantic analysis of vocabulary]. Moscow, Nauka Publ. 280 p.

Rosch E., 1973. Natural categories. Cognitive Psychology. Elsevier. Vol. 7, pp. 328-350.

Sartori C., 2000. Homo videns: Televisione e postpensiero [Homo videns: television and postthought], Rome, Laterza. $121 \mathrm{p}$.

\section{DICTIONARIES}

Krysin L.P. Tolkovyy slovar inoyazychnykh slov [Explanatory dictionary of foreign words]. Moscow, Russkiy yazyk Publ., 2001. 856 p.

Efremova T.F. Novyy slovar russkogo yazyka. Tolkovo-slovoobrazovatelnyy [New dictionary of the Russian language. Interpretative and word-forming. In 2 vols. Vol. 1]. Moscow, Russkiy yazyk Publ., 2000. 1232 p.

Ahmanova O.S. Slovar lingvisticheskih terminov [Dictionary of linguistic terms]. Moscow, Sovetskaya enciklopediya Publ., 1969. 608 p.

Sovremennyy slovar inostrannykh slov [Modern dictionary of foreign words]. Moscow, Russkiy yazyk Publ., 1993. 740 p.

Tolkovyy slovar russkogo yazyka s vklyucheniem svedeniy o proiskhozhdenii slov [Explanatory dictionary of the Russian language with the inclusion of information about the origin of words]. N.Yu. Shvedova (ed.). Moscow., Azbukovnik Publ., 2011. 1175 p.

Filosofiya: Enciklopedicheskiy slovar [Philosophy. Encyclopaedic dictionary]. A.A. Ivin (ed.). Moscow, Gardariki Publ., 2004. 1072 p.

Enciklopedicheskiy slovar: $v 2 t$. [Encyclopaedic dictionary: in 2 vol]. Moscow, Sovetskaya enciklopediya Publ., 1963. T. 1. 656 p.

\section{Information About the Authors}

Tatiana M. Shkapenko, Doctor of Sciences (Philology), Professor, Institute of Humanities, Immanuel Kant Baltic Federal University, Aleksandra Nevskogo St, 14, 236041 Kaliningrad, Russia, tshkapenko@kantiana.ru,https://orcid.org/0000-0002-6892-4205

Svetlana S. Vaulina, Doctor of Sciences (Philology), Professor, Institute of Humanities, Immanuel Kant Baltic Federal University, Aleksandra Nevskogo St, 14, 236041 Kaliningrad, Russia, svaulina@mail.ru, https://orcid.org/0000-0001-7109-2836

\section{Информация об авторах}

Татьяна Михайловна Шкапенко, доктор филологических наук, профессор Института гуманитарных наук, Балтийский федеральный университет им. Иммануила Канта, ул. Александра Невского, 14, 236041 г. Калининград, Россия, tshkapenko@kantiana.ru, https://orcid.org/0000-0002-6892-4205

Светлана Сергеевна Ваулина, доктор филологических наук, профессор Института гуманитарных наук, Балтийский федеральный университет им. Иммануила Канта, ул. Александра Невского, 14, 236041 г. Калининград, Россия, svaulina@mail.ru, https://orcid.org/0000-0001-7109-2836 